\title{
SHORT WAVES OF SUPERMARKET DIFFUSION IN TURKEY
}

\author{
Martin FRANZ, Alexandra APPEL, Markus HASSLER
}

\begin{abstract}
In order to categorize the global diffusion of supermarkets, the metaphor of waves is often used. This is a simplification, however, which obscures the fact that developments in the countries experiencing these waves of innovation are much more nuanced. This case study on the development of the Turkish grocery retail sector since the 1950s, shows how this development can be divided into different phases. Furthermore, it demonstrates that state retail chains paved the way for private actors, while most studies about the modernization of the retail sector have a focus on private companies or - even more specificallyon transnational corporations.
\end{abstract}

\section{Shrnutí}

\section{Krátké vlny difuze supermarketů v Turecku}

Ke kategorizaci globálního rozšiřování supermarketůječasto používán obrazvln. Nicménětato zjednodušená metafora zastírá skutečnost, že vývoj v zemích zasažených těmito vlnami má mnoho odlišností. Tato studie zaměřená na rozvoj tureckého potravinářského sektoru od roku 1950 ukazuje, jak müže být tento vývoj rozdělen do několika fází. Práce navíc ukazuje, že státní maloobchodní řetězce vydláždily cestu soukromým subjektům, zatímco většina obdobných studii věnovaných modernizaci maloobchodního sektoru je zaměřena na soukromé společnosti - nebo ještě konkrétněji - na nadnárodní korporace.

Keywords: food, globalization, retail, transnational, wholesale, Turkey

\section{Introduction}

The metaphor "waves of diffusion rolling along" (Reardon et al., 2003, 1142), is often used to describe different phases of the so-called "supermarket revolution" (Reardon, Hopkins, 2006, 522). The waves refer to the quantitative and spatial diffusion of supermarkets and other modern retail formats such as discounters and hypermarkets. The diffusion of such retail formats into more and more countries and regions can be understood not only as the success of a specific business model but also as the success of a series of accumulating innovations.

The first wave identified by Reardon and Minten (2011) took place in the early to mid-1990s, and included much of South America and East Asia (not including China and Japan), South Africa, the northern parts of Central Europe (including the Czech Republic: see Szczyrba et al., 2007), and the Baltic countries. The second wave rolled over much of Southeast Asia, the southern parts of Central Europe, Mexico and Central America. The third wave included Eastern and Southern Africa, other parts of Central and South America, China, India, Russia and Vietnam. In those countries, the spread of supermarkets had its take-off in the late 1990s or early 2000s. Reardon et al. (2003) and Reardon et al. (2004) cite a fourth wave beginning in the early 2000s that includes South Asia and Western Africa. These different wave categorizations are used in much of the recent literature about the processes of globalization in the retail sector (e.g. Coe and Wrigley, 2007; Humphrey, 2007; Tacconelli and Wrigley, 2009). Waves, however, are a simplifying metaphor and, as Sengupta (2008), as well as Reardon and Minten (2011), determined for India, the spread of supermarkets inside one country can occur in different phases as well.

This article tries to demonstrate, for the case of Turkey, that the 'supermarketization' of the country happened in different phases, which include waves of innovations with different reach. Furthermore, it aims to answer the following research questions: What factors start off the different waves of innovations that accompany the diffusion of modern retail formats? How do the developments in Turkey correlate or differ from those developments that are regarded as typical for the socalled supermarket revolution? The latter question 
includes an attention to the often neglected role of state institutions and cooperatives for the diffusion of modern retail formats. This article adds to knowledge about the retail sector in Turkey, and furthers a more differentiated understanding of the processes behind 'supermarketization'.

The next section presents the methodological approach of the paper. After incorporating the study in the relevant literature, the different phases of supermarket diffusion in Turkey are identified and analyzed, leading to some final conclusions.

\section{Methods}

This article presents an historical analysis of macrolevel change and innovation diffusion in Turkey, based on evidence from the literature and the analysis of primary qualitative data and secondary quantitative data. The qualitative primary data were collected during a fieldwork period from 2011 to 2012 . The authors conducted 26 expert interviews with representatives of retail and wholesale companies (including Metro Cash \& Carry, Migros Ticaret, Real and Tesco, to name only the biggest), food suppliers (e.g. Günesler and Kiliclar Gida) and retail associations (the Turkish Retail Federation PERDER and the Trade Council of shopping centres and retailers: AMPD). The interviews have been analyzed with a qualitative content analysis. The interview languages were English, German and Turkish. German and Turkish quotes have been translated into English for this article. For quantitative data, we used the Country Report Turkey 2011 of Planet Retail. Planet Retail is a retail data service (see: www.planetretail.net). Furthermore, we counted the stores on the company websites of the retail companies to gain data about the spatial diffusion of the biggest store chains (Figs. 4 and 5). After incorporating the study into the relevant literature, the different phases of supermarket diffusion are identified and analyzed. In the final section, conclusions are drawn.

\section{Waves of supermarket diffusion - reasons and impacts}

As mentioned above, the metaphor of three or four waves of supermarket diffusion is often used to describe the different phases of modernization in the food retail sector in countries of the Global South and transition countries in Central and Eastern Europe. This diffusion of modern food retail ${ }^{1}$ not only includes supermarkets, but also other format innovations such as hypermarkets, discounters and wholesale cash and carry stores. Furthermore, these formats usually come along with other innovations, e.g. in the supply chain management. An analysis of knowledge transfers in the retail sector has to differentiate between product-based (e.g. assortment, retail format, price) and process-based (e.g. expansion strategy, IT systems, logistics, supplier relationships) knowledge (Currah, Wrigley, 2004). In essence, "Retailers by the nature of competition provide a relatively high level of transparency in respect of their front of store operations with commercial success encouraging less innovative retailers to copy the formula" (Dawson, 2007, 391). Thus, process-based knowledge is of strategic importance for retailers to gain a competitive edge (Currah, Wrigley, 2004).

In many countries, the diffusion of modern retail formats was strongly connected to the emergence of foreign direct investment (FDI) in the retail sector, as transnational corporations (TNCs) such as Carrefour, Metro Group and Tesco, entered the markets and introduced innovations in formats and processes (Coe, Hess, 2005; Kulke, Pätzold, 2009). The importance of TNCs for the diffusion of modern retail formats has resulted in many studies on the geographical spread of supermarkets that focus on the transnational expansion of TNCs: "The geographical dimension of retail internationalization is a common theme in the academic literature, typified by studies measuring who went where, when, and how" (Burt et al., 2008, 79). In a series of papers, the transnational expansion of individual TNCs has been charted (e.g. Currah, Wrigley, 2003; Coe, Wrigley, 2007) or the patterns of spatial spread have been analyzed beyond company borders (e.g. Muniz-Martinez, 1998; Burt et al., 2008). However, domestic retail chains have played an important role for the diffusion of retail innovations, too (Coe and Wrigley, 2007).

The transfer of knowledge and the diffusion of supermarkets had often already started before TNCs entered the respective markets. In some countries, large domestic companies were the first movers into the supermarket business (Reardon et al., 2004): "... there are considerable transfers of management expertise between different domestic retail systems, through international searches for new ideas and technologies" (Coe, 2004, 1581).

De Rocha, Dib (2002) use the case of Brazil to show how competitive pressure due to the market entry of TNCs resulted in various attempts to implement innovations by domestic retail companies.

\footnotetext{
${ }^{1}$ We follow the definition of Romo et al. $(2009,56)$ which identifies "a minimum scale either of an independent store or a chain of stores of any scale per outlet, plus self-service" as the basic criteria for modern retail.
} 
This includes the implementation of IT systems, optimization of logistics, the introduction of bigger retail formats, as well as training courses for its own management. Managers of Brazilian retail chains visited countries in the Global North to learn more about modern retailing (learning-by-observation). Furthermore, the new formats that were introduced by TNCs in Brazil were copied by domestic companies: e.g. Sendas Group opened Send's Club, an obvious imitation of Wal-Mart's Sam's Club. After a court case, the name had to be changed into Sendas Clube.

Imitation is the one-way transfer of existing solutions from one company to another (Hammer et al., 2012). Hammer et al., (2012) differentiate between friendly and unfriendly imitation. Friendly imitation is the transfer of solutions based on cooperation between two companies. An unfriendly imitation is the transfer of a solution that is unintended by the company that is the source of the solution. The company tries to avoid such transfers or condemns the already-happened transfer of the solution (Hammer et al., 2012). Unfriendly imitation includes the imitation of transparent parts of knowledge (learning-by-observing, e.g. Malmberg and Maskell, 2002), the mobility of employees who transfer knowledge into their new companies (learning-byhiring, e.g. Song et al., 2003) or the extreme of industrial espionage (learning-by-espionage, e.g. Wright and Roy, 1999). While the last mentioned is illegal, learningby-observing and learning-by-hiring are not. As this paper will show, the diffusion of innovations in the retail sector is often based on unfriendly imitation.

A recent example for a country where indigenous companies are dominating the modern retail business is India. Retailers like Reliance Fresh or Pantaloon Retail imitated foreign role models, while the TNCs are largely restricted in their activities due to government regulations (Franz, 2010). Based on the Indian example, Reardon and Minten (2011) show the importance of state and coop chains for the diffusion of modern retail. They point out that both have been widely neglected in the debate about the diffusion of supermarkets: "Partly the neglect seems because it was not recognized that state and coop chains had and have the basic characteristics that meet the definition of 'modern retail.' The neglect seems to be due in part to retail and development researchers have been fascinated by and focused on how globalization and market liberalization and reform have touched off an explosion of private (per se) retail investment, even multinationalization"... (Reardon, Minten, 2011, 135).

Furthermore, the state chains in many countries were privatized. In Central and Eastern Europe, this happened mostly in the first half of the 1990s. An example is the Lithuanian retail company Vilniaus Prekyba, which started to buy shops from the Lithuanian state in 1992 and runs supermarkets in Estonia, Latvia, Lithuania and Bulgaria today. Reardon and Minten (2011, 135) see another reason for the neglect of the topic by recent literature in this ' 'withering away' of the state and coop food retail (and processing) segments in various countries where modern private retail has been studied". However, to paint a complete picture of the history of supermarket diffusion, these initial developments have to be integrated into the analysis.

While the motives of TNCs to invest in new markets have been widely researched and discussed (e.g. Wrigley, 2000; Reardon et al., 2003; Kulke, 2011), there are fewer analyses of the investment motives of domestic companies in the Global South or transition countries. The growing investments of retailers from North America or Europe in emerging markets beginning in the early 1990s was caused by a number of push and pull factors. Push factors include the access to low cost capital, the strong competition and consolidation, as well as tight regulations in the home markets. Pull factors are the liberalization of FDI in the retail sector and the growth opportunities in the host countries (Wrigley, 2000; Coe, Wrigley 2007). For domestic investments in the retail sector, Reardon and Minten $(2011,147)$ hypothesize that in the case of India, the expectation of liberalization of the retail sector "pervaded the retail industry and was an inducement for domestic chains to invest vigorously. That could be to establish scale and thus competitive defences ... or appear to be a good partner for an MNC [Multinational Corporation]."

Beside the reasons from the investment side, Reardon et al. $(2003,1141)$ also identify reasons from the consumer demand side that determined the diffusion of supermarkets in the Global South. These include:

- more women work outside of the home and have less time for cooking, which results in an increased demand for processed food and short shopping times;

- sinking prices for processed food due to economies of scale and growing competition between different supermarkets and food manufacturers;

- growing per capita income and the emergence of a middle class;

- diffusion of refrigerators and the resulting less frequent need to go shopping; and

- the growing number of private cars and improved public transportation.

Of course, the diffusion of supermarkets is not only a consequence of these demand side developments, but also spurs or accelerates some of the mentioned developments. 
The named push and pull factors do not always appear simultaneously. Their intensities can rise and diminish over time as they are constrained by political, economic, social and cultural developments. This may result in short waves of supermarket diffusion: i.e., a gradual modernization of the retail sector that can sometimes accelerate and sometimes decelerate, based on the changing circumstances in which it is embedded.

\section{The phases of supermarket diffusion in Turkey}

The Turkish retail sector is traditionally dominated by family-run retail outlets (Bakkallar), street vendors, markets and bazaars (Fig. 1). Planet Retail (2011, 23) estimated that there are about 550,000 Bakkals in Turkey today. However, in the 1950s, the first wave of change in the food retail sector started a process which is still ongoing. Waves are those phases in which the retail sector is changing strongly (strong diffusion of innovations). However, there can also be phases with low dynamics. The development of food retailing in Turkey, in relation to processes of globalization, can be divided into four phases, which will be presented and analyzed subsequently. The rationale for this differentiation is based on changes in the composition of the main actors in the retail sector, the introduction of innovations and their spatial diffusion, especially the modern retail formats.

\section{4-1975 - The first wave: Migros changes the retail landscape}

The first wave was not characterized by a broad spatial spread of retail innovations, but important innovations were introduced to Turkey that were catalysts for changes in the retail sector, and new actors entered the sector, including a foreign company and different state institutions. Thus, it can be said that the first wave was more qualitative than quantitative in importance.

From the foundation of the Turkish Republic in 1923 through to the late 1970s, Turkey had an importsubstitution economic policy. In 1954, the Turkish government adopted a liberal FDI Law, but still the FDI inflows were very limited (Yavan, 2010). The initial phase of retail change started in the same year with the involvement of the Swiss Migros Genossenschaft, a retail cooperative. This happened clearly ahead of the first wave of supermarket diffusion, defined by Reardon et al. (2004). In October 1953, the municipality of Istanbul, supported by the government, invited Gottlieb Duttweiler, the founder of the Swiss Migros, to bring his expertise to Istanbul. Altogether 19 private and public partners invested in the new joint venture. The main part of the investment capital, however, was provided by credits from the state-owned Ziraat Bank (Agriculture Bank) and the Yapı Kredi Bank (the first private bank in Turkey) (Özcan, 2008, 189). In this case, then, actors were involved in the founding of the Turkish Migros that are normally active on different scales and in different sectors: local actors (municipality of Istanbul), national actors (e.g. banks), and the Swiss Migros.

The aims of the Turkish institutions were to organize an effective and affordable food supply for the urban population and to control the black market. The municipality of Istanbul and the Turkish government believed that foreign knowledge was needed to improve

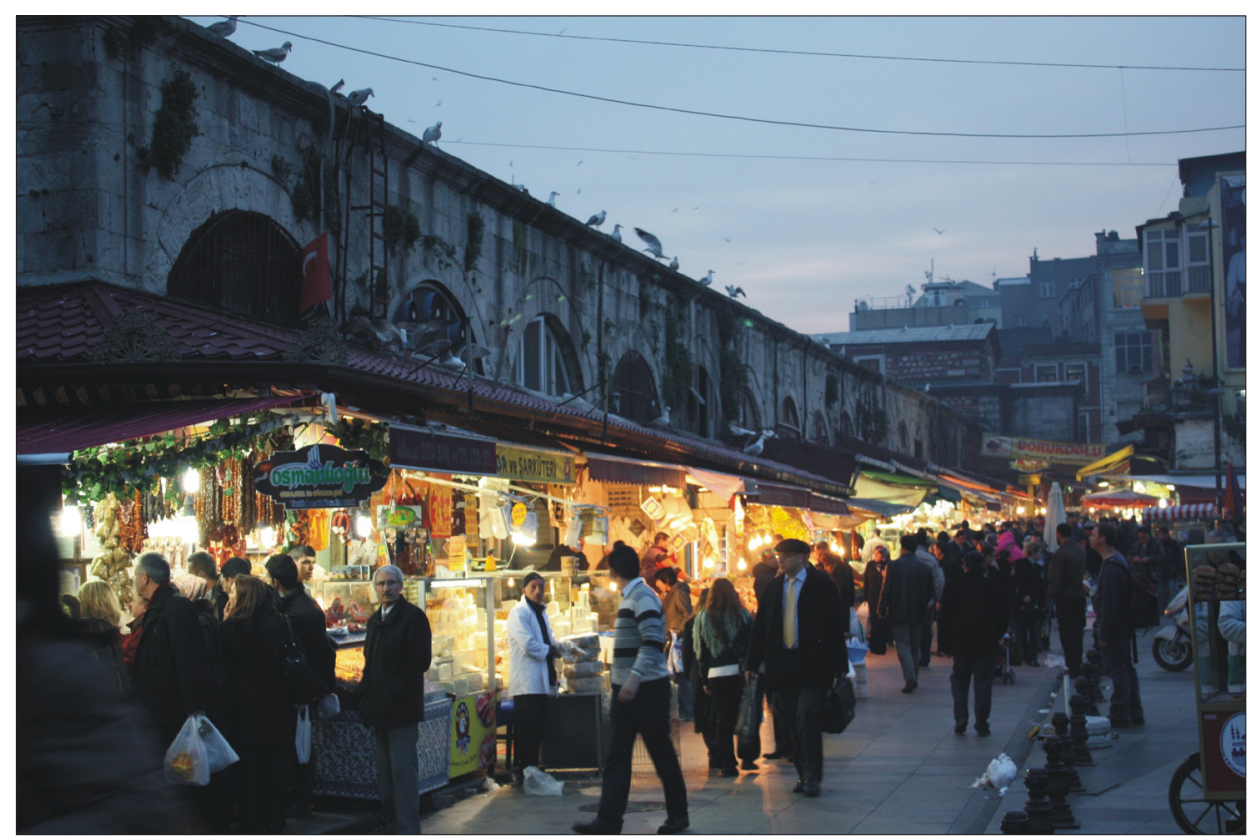

Fig. 1: The Egyptian Bazaar (Mısır Çarşısı) in Istanbul is one example of traditional retail in Turkey. Today it is a tourist attraction. (Photo: A. Appel) 
the food supply situation. This can be seen as a stateinduced knowledge transfer. The reasons for the Swiss Migros to enter the Turkish market can be attributed more to corporate social responsibility than to real business interests: “... when in 1956 the Turkish government invited him [Gottlieb Duttweiler] to come to Istanbul in order to help in developing the economy, he accepted because he saw the opportunity to serve a country which needed economic development very badly" (Hochstrasser, 1968, 42-43). The pull factors for FDI in the retail sector, which have been identified by Wrigley (2000) and Reardon et al. (2004), did not play any role in this phase, but the active courting of a foreign retailer by state institutions from a different spatial scale, did.

In the beginning, Migros Türk operated twenty mobile sales trucks. The first stationary self-service store was installed in 1957. Although the company appeared successful from the outside (by 1959 it already had sixty sales trucks, and eleven roadside stands in Istanbul), it faced many problems (Özcan, 2008, 189190). These included (1) financial losses, (2) statecontrolled prices for food products, (3) difficulties to get new trucks and spare parts for the trucks due to import and foreign exchange controls, (4) lack of skilled staff and staff fluctuations, (5) poor infrastructure, (6) cold winters and hot summers, which affected food delivery (Özcan, 2008).

As its efforts to give the undertaking a new structure were not shared by their Turkish partners, the Swiss thought that it was "expected to play a purely technical, advisory and marginal role. The venture reached the point of collapse by the end of the 1950s ... Negotiations continued and repeated assurances were given to the Swiss partners to persuade them to stay" (Özcan, 2008, 191). Migros Türk was recapitalized and Swiss Migros received a share of 51 per cent (Özcan, 2008, 191). In the 1960s, Migros Türk started to vertically integrate parts of the supply chain: a buying office was opened in the south of Turkey (Mersin), and the company became involved in food processing (Özcan, 2008).

Knowledge transfer was an important part of the Swiss Migros' engagement in Turkey. As Charles Hochstrasser $(1968,43)$, at that time Chairman of the Board of the Swiss Migros cooperatives, pointed out: "Turkish employees and workers have been trained in Switzerland and are acquainted with our ideas and our methods of working. The experiences may not have been proved 100 percent successful, but several of these people are now working in Migros Turk [sic] and doing a good job training their countrymen." Besides the training of its employees, the market entry of Migros Türk also had an indirect effect of learning-by-observing: "Individuals and companies tried to imitate Migros Turk [sic] by renewing their shops so that today you can find modern stores and supermarkets even in Anatolia. On the other hand, the efforts on the agricultural side to get standardized fruits and vegetables induced many farmers to look at this problem from a different point of view than before" (Hochstrasser, 1968, 42).

The innovations introduced to the Turkish market were not only imitated by private actors. In Ankara, a partnership of the state-owned Agricultural Bank, the Turkish Grain Board and the Günes Insurance Company, followed the Migros Türk example by founding the supermarket chain Gima A.Ş. in 1956. The Turkish Army started its own supermarket chain Ordu-Pazarları in 1963 (Oyak Corporate, 2011). At this time, private investors in Turkey did not show any interest in investing in the retail sector. Thus, local governments and consumer cooperatives were the driving forces for the second generation of supermarkets in Turkey (Özcan, 2008). While most of these chains failed, some of them were successful. The most important examples are the Tansas supermarkets, set up by the municipality of Izmir in 1973, and the already-mentioned Gima and Ordu Pazarları (Koç et al., 2008).

The development of modern retail enterprises in Turkey in the phase from 1954 to 1975 is an example of supermarket chains that were founded by state institutions. While comparable developments in other countries were often based on the engagement of central or federal states, the initiative in Turkey was taken mainly by local institutions (although it was supported by the central government) in agglomerations. Furthermore, the early cooperation between the Turkish actors and the Swiss Migros seems to be a unique case. Nevertheless, these state chains paved the way for the private actors. First, they were important contributors to a development in which the consumers in Turkeys' biggest agglomerations got slowly used to modern retail, and thus got amenable to private supermarket chains that entered the Turkish retail stage later. Second, most of them were required by their private (and often transnational) competitors to expand the store networks and to profit from their long-lasting experience in the Turkish market. There are some similarities with the developments in Central and Eastern Europe, where state institutions and state-induced cooperatives were organizing the retail sector.

The developments in the retail sector were accompanied by state efforts to make food wholesale more effective. In 1960, the law for the administration 
of wholesale markets (law No. 80) came into effect. It gave municipalities the right to open wholesale market halls $^{2}$ (Yilmaz, Yilmaz, 2008).

\section{5-1989 - The Low Dynamic Phase}

The second phase has to be characterized as a less dynamic phase in the retail sector. While private capital was still widely reluctant to invest in the retail sector on a large scale, state institutions did not intensify their efforts in the field. Thus - to stick to the wave metaphor - it can be said that this phase was more like a sea without waves, but with a slowly rising water level.

In 1975, the Swiss Migros sold its shares in Migros Türk to Koç Holding, one of the large Turkish industrial corporations. The reasons were political and economic instability, high inflation combined with controlled food prices. Migros in Turkey became Migros-Türk Limited, after an agreement with the Swiss Migros to keep the name Migros (Koç et al., 2008):

"We pay some royalties because we are using their name... But that is the only relation with them....From time to time, they want to come to Turkey and we take them and show them our locations. But we do not have to and they do not have to. But we do it since we used to have a link some years ago" (interview: Supply-chainsolutions Manager of Migros Türk, 2011).

Due to the investment of Koç, Migros became an entirely Turkish company. Koç was the first large Turkish corporation that got involved in the retail business: "At that date the company was still only an Istanbul-based retailer, with sixteen stores, thirtytwo trucks and 707 employees. Most of the equipment and merchandise was old and the facilities were in a dire condition" (Özcan, 2008, 193). The Koç Holding responded to these challenges with huge investments and the recruitment of new managers. Growth was slow, however, and in the course of the 1980s, Migros Türk lost its role as a model of modernity for the Turkish market, as the owners of the company stuck to the existing formats and strategies. It took until 1988 before the first Migros supermarket was opened outside of Istanbul (in Izmir), and even to 1990 before the first new technological upgrade was implemented (Özcan, 2008).

The slow development of Migros is representative of general developments in the Turkish retail sector. The phase between 1975 and 1989, when no transnational retailers operated in Turkey, had relatively low dynamics in the food retail sector as its main characteristic. The developments were limited to the founding of municipal supermarket chains following the example of Migros, and the slow adoption of the supermarket format by more and more local retailers (learning-by-observation). Examples include Pehlivanoğlu (founded 1980), Kiler (1981) and Beğendik (1986). These developments were already indications of the dynamics that would arise in the 1990s. Processes of liberalization, deregulation and privatization that started after the military coup in 1980 laid a basis for these dynamics. Under the pressure of the International Monetary Fund (IMF), the government started to transform the economy from an import-substituting economy towards a liberal export-orientated one. Furthermore, in 1985, the Turkish government started to stimulate modern retail with the aim to boost tax revenues (Koc et al., 2008).

\section{0-2003 - The Second Wave: The Rise of Transnational Corporations}

While the first wave brought new actors and innovations to the country, but had little spatial range, the second wave brought not only new actors (TNCs and Turkish corporations) and innovations (e.g. new formats and organizational innovations), but also a growing spatial range. The gradual liberalization that started in the 1980s became an important pull factor for FDI in the Turkish retail sector in the 1990s. Several TNCs got active in Turkey and created new market dynamics. This happened parallel to the first wave of supermarket diffusion identified by Reardon et al. (2003).

In 1990, the German-based Metro Group opened its first Cash \& Carry markets (Fig. 2), operating on a wholesale concept and addressing preferably professional customers (hotels, restaurants, catering - HORECA). It took until 1998 before Metro Group opened the first store of its hypermarket division Real: "We had a very steeply learning curve; we had to do a lot to optimize it. ... Understanding the customer's needs and demands, which always differ from country to country, often also from region to region, is crucial for our business' success. So despite all our market research, we continually had to optimize and improve our product range and offer in order to adapt to the Turkish customer" (interview representative of Metro Group, 2012).

\footnotetext{
2 The law did not include any rules concerning product quality, standardization or prices, but gave the municipalities the right to fill this gap with its own regulations. It took until 1995 before the Government Decree (No. 552) for "Regulation of Trading of Fresh Fruits and Vegetables and Wholesale Markets" regulated product quality, standardization and prices for wholesale markets Turkey-wide (Yilmaz, Yilmaz, 2008).
} 
Carrefour entered the Turkish market in 1991. Since 1996, Carrefour formed a joint venture with the Turkish conglomerate Sabanci Holding under the name Carrefour SA in Turkey. Following the launch of Metro Cash \& Carry and Carrefour, numerous transnational, regional and local retail chains became active in Turkey. The Spanish discounter $\mathrm{Dia}^{3}$ opened its Turkish subsidiaries in 1999. The British Tesco took over the supermarket chain Kipa in Izmir in 2003, and expanded along the west and south coast (Fig. 3).
Although a number of TNCs entered Turkey during this phase, it is noteworthy that a lot of TNCs that were part of the "supermarket revolution" (Reardon, Hopkins, 2006, 522) in Central and Eastern Europe did not enter Turkey (e.g. Aldi, Auchan, Rewe Group, Schwarz Group). They partly (e.g. Aldi, Rewe Group and Schwarz Group) focused their investment and management on expansion in Central and Eastern Europe (e.g. Dries et al., 2004). Others (e.g. Ahold and Delhaize) were also attracted by the opportunities for

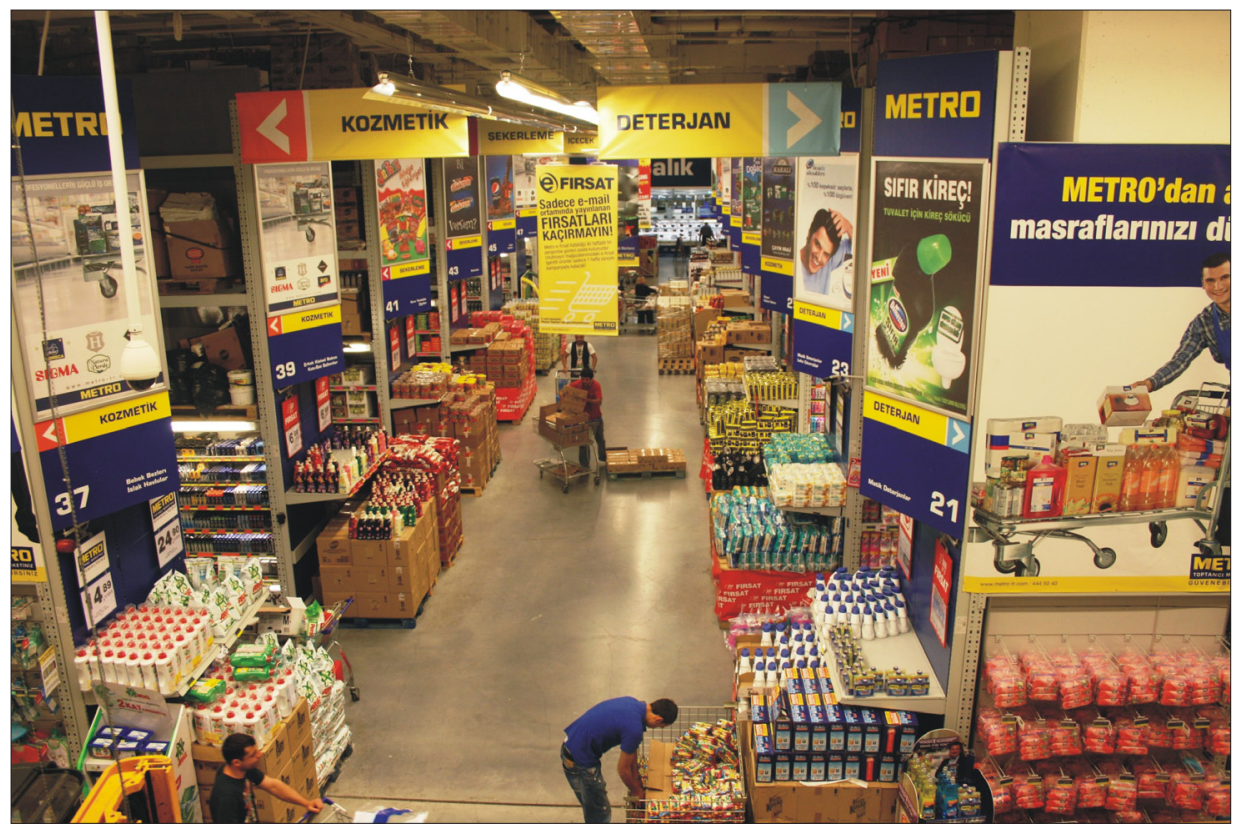

Fig. 2: Metro Cash\&Carry store in Istanbul (Photo: M. Franz)

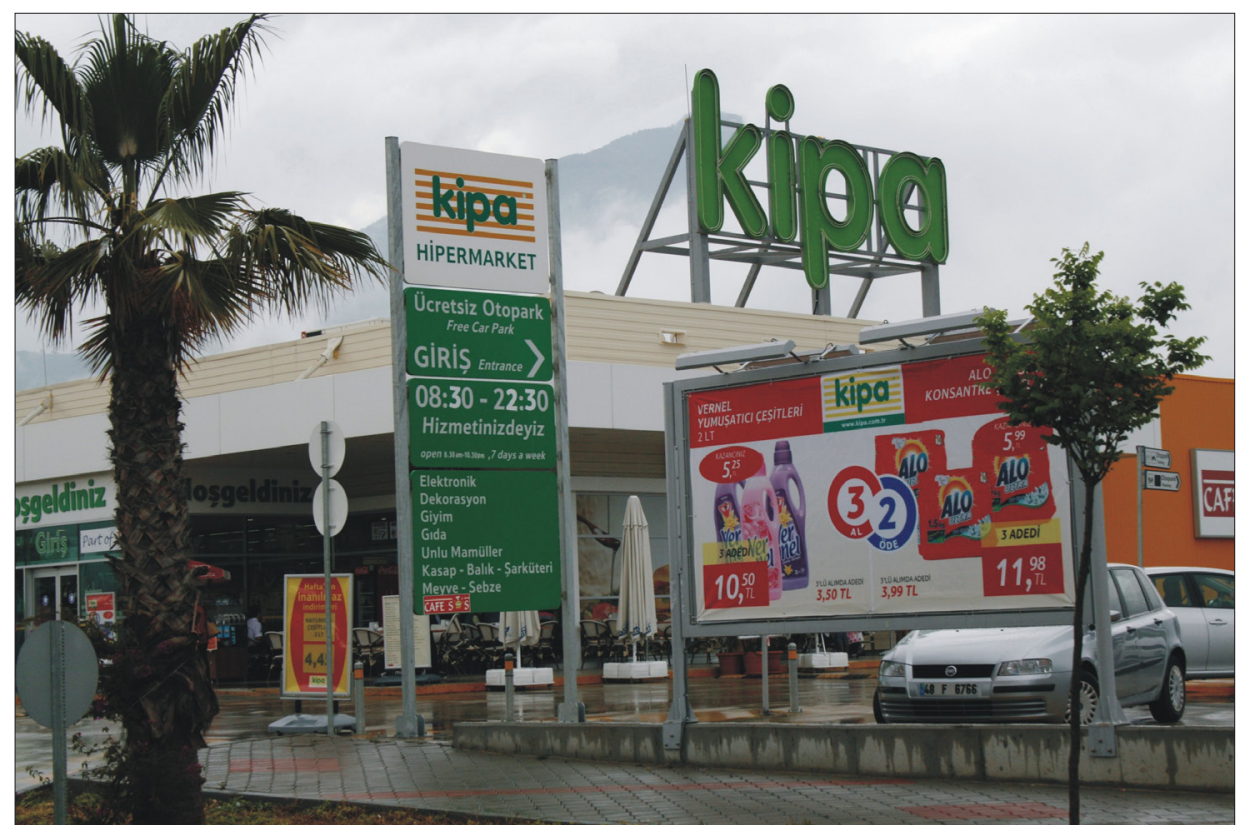

Fig. 3: Kipa store in Fethiye. The hypermarkets belong to the UK-chain Tesco (Photo: M. Franz)

\footnotetext{
${ }^{3}$ A year later Dia was taken over by Carrefour. Dia in Turkey became a joint venture between Carrefour and Sabanci Holding and operates since then in Turkey under the name DiaSA. In 2011 Carrefour in Spain brought Dia in the stock market (see Table 2). Thus, Dia became once again an independent company based in Spain (Carrefour, 2011).
} 
cheap investments in existing assets in South East Asia in the aftermath of the Asian crisis in 1997 and invested there (e.g. Mutebi, 2007). Furthermore, those who entered Turkey did not advance with the expansion in the market as fast as they did elsewhere (e.g. Carrefour and Metro Group) or entered relatively late (Tesco). This unassertive behaviour of the companies seems to be partly related to political developments: "Our investment in the Turkish business was done step by step - mainly due to the turbulent political circumstances over the past years" (interview representative of Metro Group, 2012).

However, in this period, foreign role models were increasingly imitated by Turkish companies in terms of formats, services, product range and marketing techniques (learning-by-observing). In some cases, foreign managers or Turkish managers that had gained experience in TNCs were hired by Turkish companies (learning-by-hiring). The increasing market dynamics, as well as the knowledge transfers after the market entry of TNCs, reflect developments that have been observed for other markets. One characteristic for the developments of the 1990s in Turkey is the increasing diversification of formats, including the introduction of discount stores and hypermarkets. Turkey's first discount chain, BIM, was established in 1995: "They brought know- how. ... Especially BIM changed the way of doing things a lot" (interview Macromarket format manager of Migros Türk, 2011). BIM is an imitation of the German discount retailer ALDI. The know-how was transferred by consulting a former ALDI manager (learning-by-hiring) and the training of some members of management in Germany. Shortly after, Migros Türk established its own discount brand, named Şok. Besides BIM and Şok, today the major discount chains are Dia SA and A101. In comparison to super- and hypermarkets, discounters have a higher number of branches and wider geographical distribution all over Turkey (Franz and Hassler, 2011). This may be linked to the lower need for capital per store, less infrastructure requirements and the lower potential exit cost. While the success of discounters was bigger than expected, "the hypermarket concept grew slower than anticipated" (Planet Retail, 2011, 18). The high investment requirements and the potential exit costs discouraged investors from a stronger engagement in the hypermarket sector.

Besides the format diversification, organizational innovations were also undertaken. For example, credit card payment and customer loyalty cards were introduced. Also noteworthy is the early introduction of on-line grocery retail by Migros Türk in 1999. Starting in 1997, Turkish companies also invested abroad (Migros Türk started in Azerbaijan, later on it invested in Kazakhstan, Russia, Bulgaria, Macedonia and
Kirgizia; Gima in Bulgaria and Russia; Koç et al., 2008). They are part of the strong transnational expansion of second-tier retail TNCs identified by Dawson (2007).

\section{3 - Today - Third Wave: Diffusion and Consolidation}

While the main drivers of the second wave were the impacts of policy changes that started in the decade before, the year 2003 brought a change in the politicoeconomic developments in Turkey that proved to have a great influence on the retail sector. As it also marked a change in the speed and spatial range of the developments, it can be seen as the start of a new wave.

In 2003, the Justice and Development Party (Turkish: Adalet ve Kalkınma Partisi - AKP) won the election as a moderate Islamic and neoliberal party. Under the new leadership, liberalization was taken forward and investors became more confident due to the growing political stability in the country. These political developments, together with the growing purchasing power of consumers in Turkey, had impacts on the retail sector: TNCs intensified their investments (Fig. 4): "Turkey is one the focus countries for Metro Group in terms of investment and expansion now. We see a huge potential in the Turkish market with its economic growth, demographic structure and the general business-friendly environment" (interview, representative of Metro Group, 2012).

The growing FDI in the sector was one of the reasons for far-reaching horizontal consolidation processes. Other reasons included the falling margins in the sector, increasing competition at attractive locations and between different formats (supermarket, hypermarket, discounter), and the strategy to buy regionally well-known chains to accelerate expansion, and to avoid problems of embeddedness that potentially would have occurred in organic growth. The consolidation processes took place in a similar manner, but faster than the developments in many parts of North America and Western Europe in the second half of the $20^{\text {th }}$ century. Migros Türk took over the local or regional chains Tansaş (2005), Maxi (2008) and Yonca (2009). CarrefourSA acquired the chains Gima (2005, including Endi discount stores which became part of DiaSA) and Pınar Marketçilik (2009). The Kiler Group bought Canerler Marketler (2005), Güler Market (2006), Karıncalar (2007), and a number of stores from the struggling competitor Yimpaş. Makromarket bought Nazar (2007), Afra (2008), Kaya and Eras (2009) and merged with Uyum (2007) (Koç et al., 2008; company websites).

However, there is still a confusing amount of local and regional chains and the top five players only hold a market share of less than 10 percent (Planet 
Retail, 2011, 23). As the head of the association of Turkish food retailers, Perder, stated in an interview, over 450 locally and regionally operating grocery retail chains are present: "You can see local brands you have never heard of dominating the market against certain international huge success stories" (interview, representative of a food wholesale company, 2011). Many of the locally and regionally operating chains copy the strategies of discounters. On the other hand, they introduce high-end formats. In general, a trend of

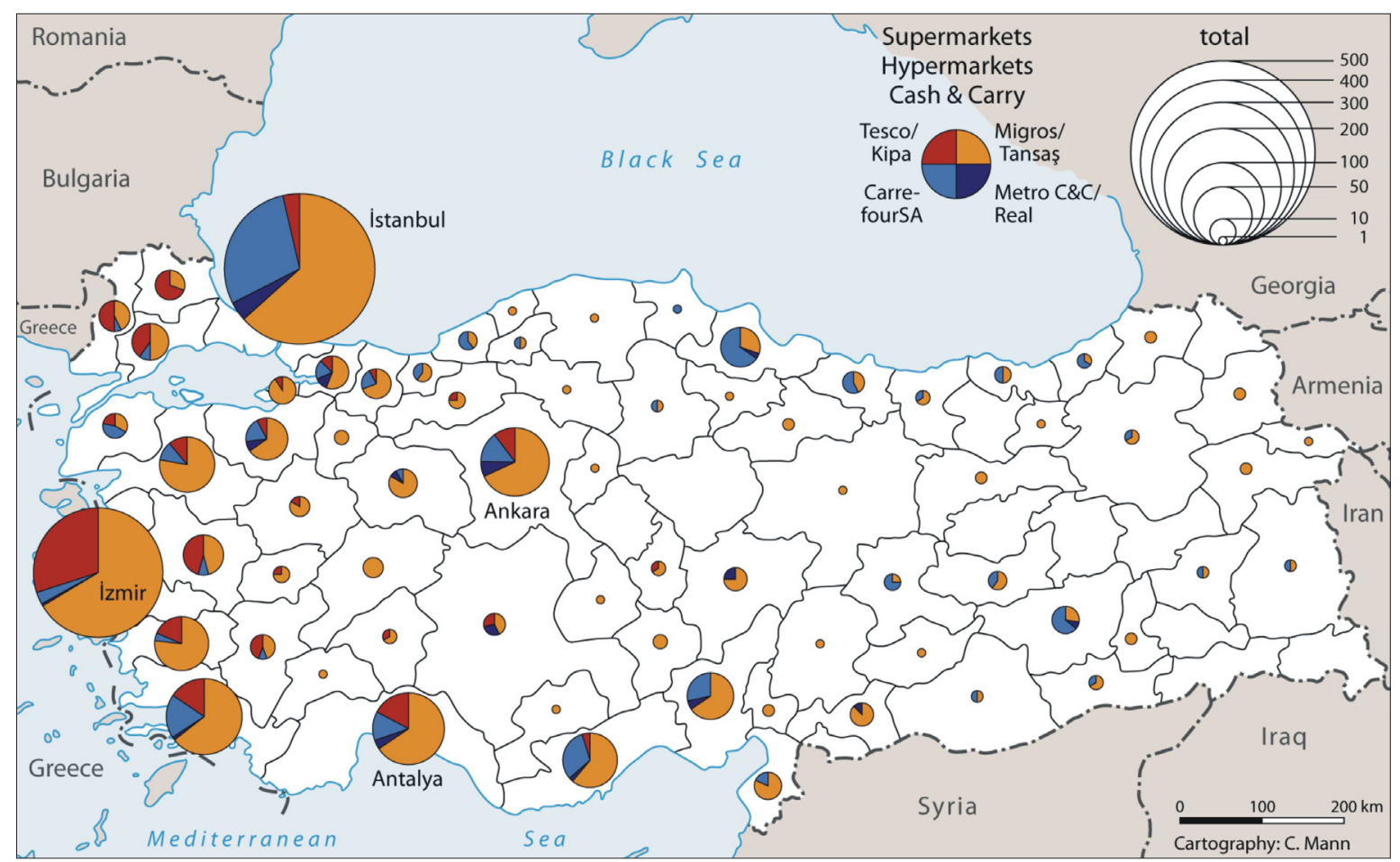

Fig. 4: The spatial diffusion of supermarkets, hypermarkets and cash \& carry markets of selected companies in Turkey in December 2012

Sources: company websites, elaboration: C. Mann

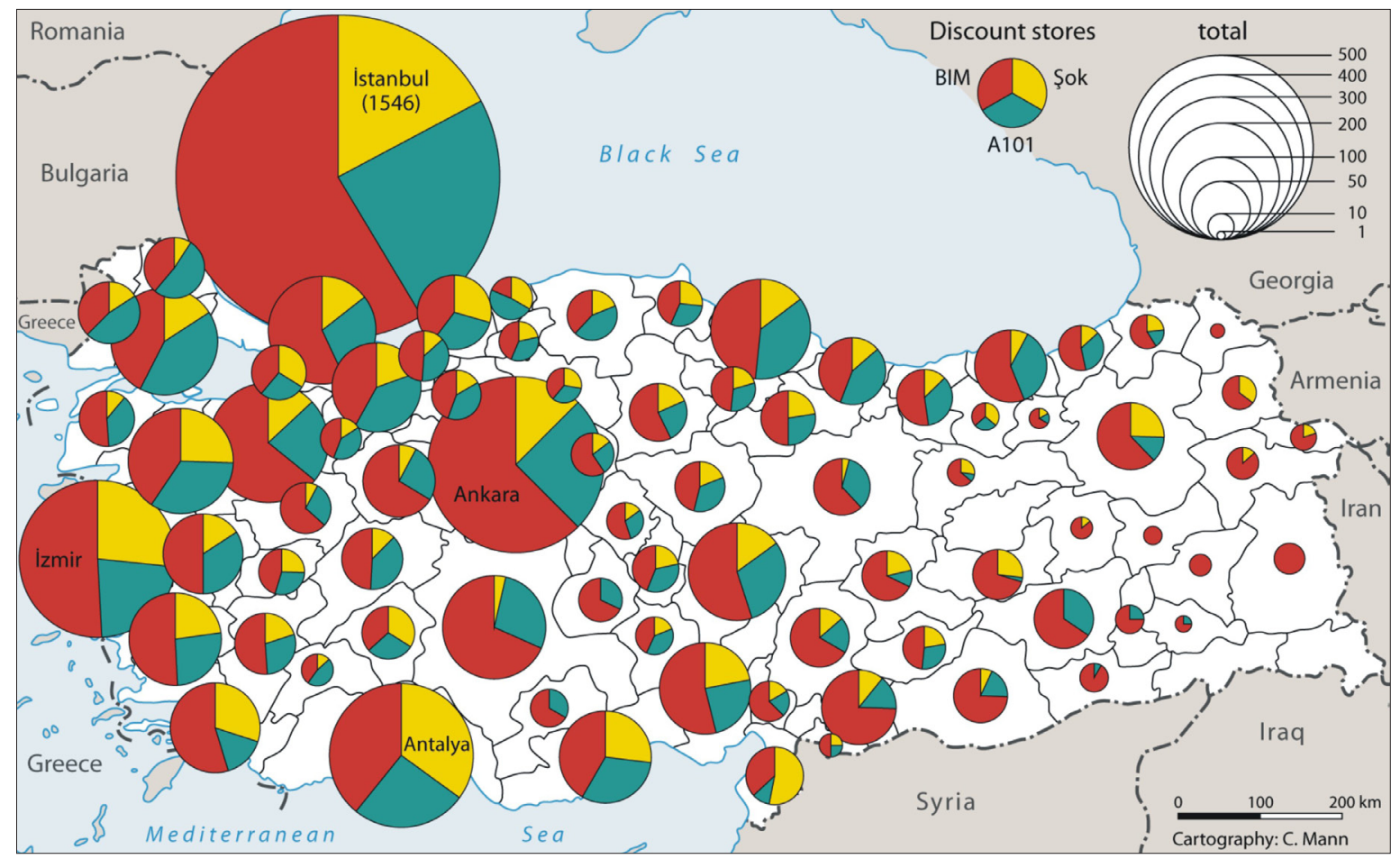

Fig. 5: The spatial diffusion of the three largest discount store chains in Turkey in December 2012 Sources: company websites, elaboration: C. Mann 
chaining-up of smaller actors can be identified: "Local traditional one-spot retail markets ... have a tendency to organize up ... either by themselves by branching up or joining forces with others in that manner" (interview, representative of a food wholesale company, 2011). These developments include a harmonization of the product as well as the process knowledge between TNCs, Turkish corporations and regional players by observation and strong employee mobility between the different companies. One new development of this phase is the development of retail cooperatives in which small retailers unite to keep a competitive basis. The first one was founded in 2006 in Inegöl (Bursa region).

While new actors are entering the retail scene, others are leaving it. Huge business conglomerates reorganize themselves and sell their shares to retail companies because of the falling margins (Karadağ, 2010). Thus, Koç sold the majority of its shares in Migros Türk in 2008 to the British private equity fund BC Partners. Migros became the new name Migros Ticaret. Three years later BC Partners sold the Migros Ticaret discount chain Şok to Ülker: "It's a strategic decision. They want to focus on the supermarket and hypermarket issue. The discount issue is very different from the supermarket issue ... (It's) not a sales operation but a logistics operation" (interview with manager of Şok, 2011).

During the 2000s, modern formats diffused into smaller agglomerations, similar to the third wave described by Reardon et al. (2003). Among those were cities highly frequented by tourists, as well as areas with increasing economic activity and thus a rising amount of people in the middle-class income group. Table 1 gives an overview of the top five grocery retailers, Figure 4 and 5 give an overview of the diffusion of the most important retail companies. It can be seen that there is still a stronger distribution of the stores in the west of the country.

Due to economic development, reforms and changes in consumer demand (Reardon et al., 2003, 1141), hypermarkets grew quickly after 1999 in large cities (there are no general size restrictions for retail stores in Turkey which would limit the expansion of hypermarkets): "Here consumers are more aware of international trends, have higher disposable incomes and have automobiles to travel to and from the stores. However, it is not easy for the sector to expand at a high speed: in many cases the search for large sites cause [sic] substantial difficulties owing to administrative hurdles" (Planet Retail, 2011, 18). The diffusion of super- and hypermarkets was and is sometimes accompanied by the development of shopping malls: "... many large supermarkets encourage purposebuilt shopping centre developments (such as Migros in Istanbul's Atrium shopping centre or Begendik in Istanbul's Carrousel shopping centre), or play a more direct role in the development of their own shopping centres (such as Carrefour in Istanbul's Carrefour shopping centre and Migros in Migros shopping centre in Beylikdüzü, Istanbul)" (Tokatli and Boyaci, 1998, 354). In 2009, there were 236 Shopping Centres in Turkey (PWC Turkey, 2011, 112).

Discount stores in Turkey, already established in the previous phase, were also successful (Fig. 5 and Tab. 2). They increasingly put pressure on the other formats with cheap prices, a close-meshed net of markets, and an aggressive and early expansion into new locations. Thus, many companies seem to put more efforts on the expansion of their discount formats than on hypermarkets (Planet Retail, 2011). This shows that there is great potential in emerging markets for a format that is not confined to the middle- and upper-income groups. This is affirmed by the successful expansion of the Turkish discount chain BIM in Morocco with 110 stores at the end of 2012 (BIM 2013, 3). Both formats, hypermarkets and discounters, are important product-based innovations that have spread with different intensity. Due to the differences in catchment areas (huge catchment areas for hypermarkets), investment needs (lower investment

\begin{tabular}{|l|l|c|c|c|c|}
\hline \multicolumn{1}{|c|}{ Company } & \multicolumn{1}{|c|}{ Country of origin } & $\begin{array}{c}\text { Number of } \\
\text { Outlets }\end{array}$ & $\begin{array}{c}\text { Total Sales } \\
\text { Area SQM }\end{array}$ & $\begin{array}{c}\text { Average Sales } \\
\text { Area SQM }\end{array}$ & $\begin{array}{c}\text { Grocery Retail } \\
\text { Banner Sales (EUR) }\end{array}$ \\
\hline BIM & $\begin{array}{l}\text { Turkey (investors from } \\
\text { USA and Saudi Arabia) }\end{array}$ & 2,951 & $1,215,812$ & 412 & $3,013,659,522$ \\
\hline Migros Ticaret & $\begin{array}{l}\text { Turkey (owned by } \\
\text { British investment fond) }\end{array}$ & 1,902 & 939,845 & 494 & $2,729,859,601$ \\
\hline CarrefourSA (incl. DiaSA) & $\begin{array}{l}\text { France and Turkey } \\
\text { (joint venture) }\end{array}$ & 1,138 & 579,360 & 509 & $1,276,416,890$ \\
\hline Metro Group & Germany & 31 & 275,200 & 8,877 & $944,156,429$ \\
\hline Tesco & UK & 121 & 286,332 & 2,366 & $598,200,600$ \\
\hline
\end{tabular}

Tab. 1: Top five grocery retailers 2010

Source: Planet Retail, 2011, 25 


\begin{tabular}{|c|c|c|c|c|c|c|c|c|}
\hline \multirow{2}{*}{ Year } & \multicolumn{2}{|c|}{ Supermarkets, hypermarkets, cash \& carry markets } & \multicolumn{4}{c|}{ Discount store chains } \\
\cline { 2 - 9 } & CarrefourSA & $\begin{array}{c}\text { Metro } \\
\text { Cash \& Carry } \\
\text { and Real }\end{array}$ & $\begin{array}{c}\text { Migros } \\
\text { and Tansas }\end{array}$ & Tesco/Kipa & A101 & BIM & DiaSA & Şok \\
\hline $\mathbf{2 0 1 0}$ & 248 & 31 & $1,902^{*}$ & 121 & No data & 2,951 & 890 & No data \\
\hline $\mathbf{2 0 1 2}$ & 242 & 40 & 852 & 188 & 1,784 & 3,556 & 1,093 & 1,217 \\
\hline
\end{tabular}

Tab. 2: The number of outlets of selected companies in Turkey in 2010 and 2012.

Sources: Planet Retail, 2011, 25 and company websites. Note: *including Şok

per store for discounters), risks (higher potential exit costs for hypermarkets) and target groups (higher income groups for hypermarkets), discounters have reached higher quantities and are already successful in smaller and less developed cities of Turkey (Fig. 5).

As the chains of large retail companies reach more parts of Anatolia, new challenges await their distribution networks. While, for a long time, the distribution networks were focused on the western part of Turkey, the companies now have to bridge long distances in Central and Eastern Anatolia. This is a challenge for the food processing companies, too. Until now, they were mostly concentrated in the Istanbul region and not adjusted for country-wide distribution. Thus, a further diffusion of process-based knowledge can be expected. The situation concerning the large suppliers of fruits and vegetables is not improved: "At Metro Cash and Carry in general we source over 90\% of our products from local suppliers ... However, this has been quite a challenge in Turkey because in the past most of the Turkish suppliers, especially the ones offering good quality, focused much more on export than on building a national distribution network. It is only a recent trend that Turkish companies are trying to really focus on establishing a proper country-wide distribution network in order to meet growing demand and quality requirements" (interview, Supply Chain Manager of Metro Cash \& Carry, 2012).

Further changes could happen in the aftermath of an expected further liberalization of food wholesale, which is desired by many modern retailers. It has often been argued that the existing marketing system, which dictates the trade in wholesale markets, is protecting the role of intermediaries and disadvantages producers and consumers (Yilmaz, Yilmaz, 2008).

Although the growth of modern retail companies is partly happening very fast (Tab. 2), the traditional retail formats still have a dominant role in the Turkish food retail sector. This is especially true in rural areas and small towns, as the presence of supermarkets, hypermarkets and discounters is limited there (Planet Retail, 2011). The east still dwells on agriculture and largely suffers from its remoteness. However, those are the areas which are increasingly targeted by retail companies: "New, fast-growing economic centres have developed [in the central and eastern parts of Turkey], some of which show even better economic growth rates than the rest of the country. Among these, new industrial and economic centres are for example Kayseri, Adana, Diyarbakır, Gaziantep and many others. So ... if you want to do further expansion in Turkey, you have to move further to the east" (interview, Board Member of Metro Cash \& Carry Turkey, 2012).

While there are still some untapped potentials in the east, the competition is generally getting stronger and margins are narrowing due to high competition and consumers' strong price-sensitivity (Euromonitor International, 2011).

Promoting on-line shopping, which is a product as well as a process-based innovation in the food retail sector, turns out to be one strategy to face the falling margins and can contribute to further growth and outreach. Especially, the increasing spread of mobile internet devices such as smart phones or tablet PCs, can mobilize customers to adopt new channels. Already, posters of store shelves have been set up by Migros to make customers aware of on-line shopping possibilities. The customers can directly scan products QR codes from the posters and place their order online. It seems that for parts of the Turkish society, material supermarkets may only be a short interlude between traditional retail and on-line shopping.

\section{Conclusions}

To categorize the global diffusion of supermarkets, the picture of waves rolling along is often used. However, this simplifying metaphor clouds the developments in different countries hit by these supermarket waves, which are much more differentiated. In general, the case of Turkey shows that the development of different phases or waves of the diffusion of retail innovation inside one country can be driven by a variety of interwoven factors, including institutional, economic and cultural aspects. At the level of state institutions, the development includes direct investments of state institutions in the retail sector, direct incentives for retail companies like subsidies and courting for FDI, as well as indirect incentives (liberalization, 
deregulation). Furthermore, the political stability in a country can spur developments in the retail sector. From the economic perspective, economic growth, grades of competition, transfer of knowledge from other markets and capital availability seem to be the main factors. Growing demand is not only a consequence of higher incomes, but also of cultural changes, for example in family structures.

This case study of the development of the Turkish retail sector from the 1950s shows how the so-called supermarket revolution was based on short waves of innovations, changing actor constellations, and a growing spatial range of the diffusion of modern retail formats.

Major development trends are listed as follows:

- 1954-1975: State institutions which are normally active on different scales (municipalities, stateowned banks, state agencies, army, etc.) played a major role in the introduction of modern retail, as they established new retail companies and attracted the Swiss Migros to transfer knowledge to Turkey;

- 1975-1989: The phase in which no TNCs operated in Turkey, and thus had low dynamics in the Turkish grocery retail sector. Developments were limited to the founding of state and cooperative supermarket chains in urban agglomerations, and the slow adoption of the supermarket format by local retailers (learning-by-observing). The retail knowledge that was imported in the previous phase diffused in Turkey, but the transfer of new retail knowledge into the country was very limited;

- 1990-2003: The advent of retail TNCs in Turkey sparked new dynamics in the sector. However, the TNCs were still not assertive in their investments mainly due to the absence of political stability in the country. Nevertheless, foreign role models were increasingly copied by Turkish companies and a strong differentiation of retail formats (supermarkets, hypermarkets, discounters) changed the Turkish retail landscape (learning-byobserving and learning-by-hiring); and

- Since 2003: The stronger political stability, combined with neo-liberal policies, acted as a pull factor for FDI. FDI, falling margins, increasing competition at attractive locations and between different formats, resulted in market consolidation. However, Turkey is still characterized by a highly fragmented retail landscape.

The first, third and fourth phase can be considered as different short waves not only of investments and supermarket diffusion, but also of knowledge transfer. Current developments can be a sign that a new wave is on its way: the wave of grocery e-commerce.
The different phases also had different impacts on the supply systems. While the impact was still low during the first two phases (first short wave, phase of low dynamics), it was growing fast during the second short wave. However, it was still limited to the development of food processing and logistics, mainly in Istanbul and partly in other large agglomerations.

Nevertheless, most large fresh food suppliers were strongly focused on export. In the course of the third wave, the pattern changed. The Turkish retail sector was an increasingly attractive buyer for big suppliers and the demand spreads from Istanbul and the western part of Turkey to most of the country. Suppliers react with the development of new distribution networks, which are adequate to supply their goods to retailers all over the county.

This case study shows that state and cooperative retail chains paved the way for private actors, while most studies about the modernization of the retail sector have a strong focus on private companies or - even more specifically - on transnational corporations. Until 1990, state institutions and cooperative actors were the key drivers of retail innovations in Turkey. Later, the entry of transnational corporations in the market - headed by Metro Group and Carrefour - strongly influenced the Turkish retail scene, not only because of their own economic activities but also because they functioned as role models for other retailers.

Generally, the institutional changes that spurred developments in the retail sector during the last centuries can be seen as an example of changes in times of a neo-liberal policy agenda (Karadağ, 2010). As Karadağ $(2010,29)$ emphasizes: "Similar regime dynamics and patterns of legitimization exist in other countries and regions that have experienced the transformation and retrenchment of the state, for example, in Latin America and Southeast Asia. Elites in oligarchic settings face the challenge of political contestation in highly fragmented configurations".

However, there are not only similarities with other countries at an institutional level, but also concerning the developments in the retail sector itself. In Central and Eastern Europe, state institutions and stateinduced cooperatives were organizing the retail sector before 1990, although in a much more extensive way too. These retail chains also paved the way for private actors, who took over their businesses in many cases after 'liberalization'. However, in most countries of Central and Eastern Europe, the spatial diffusion of supermarkets, hypermarkets and discounters happened much faster after 1990 than in Turkey (see e.g. Dries et al., 2004). 


\section{References:}

BIM (2013): Annual Report 2012 [online]. [cit. 07.10.2013]. Available at: URL: www.bim.com.tr/english/Uploads/ dosyalar/1_12591379_bim_eng_2012.pdf

BROWN, S. (1987): Institutional Change in Retailing: A Review and Synthesis. European Journal of Marketing, Vol. 21, No. 6, p. 5-36.

BURT, S., DAVIES, K., DAWSON, J., SPARKS, L. (2008): Categorizing patterns and processes in retail grocery internationalisation. Journal of Retailing and Consumer Services, Vol. 15, No. 2, p. 78-92.

CARREFOUR (2011): Carrefour acquires 100\% of Dia from its subsidiary Norfin Holder S. L. prior to the distribution of the Dia shares by Carrefour [online]. [cit. 05.10.2011]. Available at: URL: www.carrefour.com/docroot/groupe/C4com/ Pieces_jointes/Communiques_financiers/2011/DIACOMMUNIQUE01072011UK.pdf

COE, N. M. (2004): The internationalization/ globalisation of retailing: towards an economic geographical research agenda. Environment and Planning A, Vol. 36, p. 1571-1594.

COE, N. M., HESS, M. (2005): The internationalization of retailing: implications for supply network restructuring in East Asia and Eastern Europe. Journal of Economic Geography, Vol. 5, No. 4, p. 449-473.

COE, N. M., WRIGLEY, N. (2007): Host economy impacts of retail TNCs: the research agenda. Journal of Economic Geography, Vol. 7, No. 4, p. 341-371.

CURRAH, A., WRIGLEY, N. (2004): Networks of organizational learning and adaptation in retail TNCs. Global Networks, Vol. 4, No. 1, p. 1-23.

DAWSON, J. A. (2007): Scoping and conceptualising retailer internationalisation. Journal of Economic Geography, Vol. 7, No. 4, p. 373-397.

DE ROCHA, A., DIB, L. A. (2002): The entry of Wal-Mart in Brazil and the competitive responses of multinational and domestic firms. International Journal of Retail and Distribution Management, Vol. 30, No. 1, p. 61-73.

DRIES, L., REARDON, T.; SWINNEN, J. F. M. (2004): The Rapid Rise of Supermarkets in Central and Eastern Europe: Implications for the Agrifood Sector and Rural Development. Development Policy Review, Vol. 22, No. 5, p. 525-556.

EUROMONITOR INTERNATIONAL (2011): Retailing - Turkey. London.

FRANZ, M. (2010): The role of resistance in a retail production network: protests against supermarkets in India. Singapore Journal of Tropical Geography, Vol. 31, No. 3, p. 317-329.

FRANZ, M., HASSLER, M. (2011): Globalisierung durch Supermärkte - Transnationale Einzelhändler in der Türkei. Geographische Rundschau, Vol. 63, No. 5, p. 28-34.

HAMMER, I., BECK, S., GLÜCKLER, J. (2012): Lernen im lokalen Unternehmensnetzwerk: Imitation zwischen Konvention und Tabu. In: GLÜCKLER, J., DEHNING, W., JANNECK, M., ARMBRÜSTER, T. [eds.]: Unternehmensnetzwerke. Architekturen, Strukturen und Strategien. Heidelberg: Unternehmensnetzwerke - Architekturen, Strukturen und Strategien. Heidelberg, Springer, p. 163-182.

HOCHSTRASSER, C. H. (1968): Opportunities and responsibilities of retailers around the World. Journal of Retailing, Vol. 44, No. 1, p. 38-44.

HUMPHREY, J. (2007): The supermarket revolution in developing countries: tidal wave or tough competitive struggle? Journal of Economic Geography, Vol. 7, p. 433-450.

KARADAĞ, R. (2010): Neoliberal Restructuring in Turkey - From State to Oligarchic Capitalism. MPIfG [Max Planck Institut für Gesellschaftsforschung] Discussion Paper 10/7. [online]. [cit. 23.04.2012]. Available at: URL: www.mpifg.de/ pu/mpifg_dp/dp10-7.pdf, 23.4.2012.

KOÇ, A. A., CODRON, J.-M., TEKELIOĞLU, Y., LEMEILLEUR, S., TOZANLI, S., AKSOY, Ş., BIGNEBAT, C., DEMIRER, R., MENCET, N. (2008): Agrifood Sector Studies - Restructuring of Agrifood chains in Turkey: The produce Sector (A). In: Regoverning Markets - Small Scale Producers in modern Agrifood Markets. [online]. [cit. 05.10.2011]. Available at: URL: www.regoverningmarkets.org/en/filemanager/active?fid $=743$

KULKE, E. (2011): Internationalisierung des Einzelhandels - das Beispiel IKEA. Geographische Rundschau, Vol. 63, No. 5, p. $12-19$.

KULKE, E., PÄTZOLD, K. [eds.] (2009): Internationalisierung des Einzelhandels - Untersuchungsstrategien und Anpassungsmechanismen. Geographische Handelsforschung 15, Passau.

MALMBERG, A., MASKELL, P. (2002): The elusive concept of localization economies: Towards a knowledge-based theory of spatial clustering. Environment and Planning A, Vol. 34, p. 429-449.

MUNIZ-MARTINEZ, N. (1998): The internationalisation of European retailers in America: the US experience. International Journal of Retail and Distribution Management, Vol. 26, No. 1, p. 29-37. 
MUTEBI, A. (2007): Regulatory Responses to Large-format Transnational Retail in South-East Asian Cities. Urban Studies, Vol. 44, No. 2, p. 357-379.

OYAK CORPORATE (2011): Corporate History 1961-1970 [online]. [cit. 29.08.2011]. Available at: URL: www.oyak.com.tr/ EN/corporate/corporate-history/1961-1970.html.

ÖZCAN, G. B. (2008): Surviving through transplantation and cloning: The Swiss Migros hybrid, Migros-Türk. In: Smith, C. [ed.] Remaking Management. Cambridge: Cambridge University Press, p. 181-205.

PLANET RETAIL (2011): Country Report Turkey. London.

PWC TURKEY (2011): Shining Star - The Effects of the Retail Industry on the Turkish Economy. Istanbul: PWC Turkey.

REARDON, T., HOPKINS, R. (2006): The supermarket revolution in developing countries: policies to address emerging tensions among supermarkets, suppliers, and traditional retailers. European Journal of Development Research, Vol. 18, No. 4, p. 522-545.

REARDON, T., MINTEN, B. (2011): Surprised by supermarkets: diffusion of modern food retail in India. Journal of Agribusiness in Developing and Emerging Economies, Vol. 1, No. 2, p. 134-161.

REARDON, T., TIMMER, P., BARRRET, C. B., BERDEGUE, J. (2003): The rise of supermarkets in Africa, Asia, and Latin America. American Journal of Agricultural Economics, Vol. 85, No. 5, p. 1140-1146.

REARDON, T., TIMMER, P., BERDEGUE, J. (2004): The Rapid Rise of Supermarkets in Developing Countries: Induced Organizational, Institutional, and Technological Change in Agrifood Systems. Electronic Journal of Agricultural and Development Economics, Vol. 1, No. 2, p. 168-183.

ROMO, G. D., DIGAL, L., REARDON, T. (2009): The Transformation of Food Retail in the Philippines. Asian Journal of Agriculture and Development, Vol. 6, No. 2, p. 51-84.

SENGUPTA, A. (2008): Emergence of modern Indian retail: an historical perspective. International Journal of Retail \& Distribution Management, Vol. 36, p. 689-700.

SONG, J., ALMEIDA, P., WU, G. (2003): Learning-by-Hiring: When Is Mobility More Likely to Facilitate Interfirm Knowledge Transfer? Management Science, Vol. 49, No. 4, p. 351-365.

SZCZYRBA, Z., KUNC, J., KLAPKA, P., TONEV, P. (2007): Difúzní procesy v prostředí českého maloobchodu. Regionální studia, Vol. 1, No. 1, p. 8-12.

TACCONELLI, W., WRIGLEY, N. (2009): Organizational challenges and strategic responses of retail TNCs in post-WTOentry China. Economic Geography, Vol. 85, p. 149-173.

TOKATLI, N., BOYACI, Y. (1998): The changing retail industry and retail landscapes - The case of post-1980 Turkey. Cities, Vol. 15, No. 5, p. 345-359.

WRIGHT, P. C., ROY, G. (1999): Industrial espionage and competitive intelligence: one you do; one you do not. Journal of Workplace Learning, Vol. 11, No. 2, p. 53-59.

WRIGLEY, N. (2000): The globalization of retail capital: themes for economic geography. In: CLARK, G. L., FELDMAN, M. P., GERTLER, M. S. [eds.]: The Oxford Handbook of Economic Geography. Oxford, Oxford University Press, p. 292-313.

YAVAN, N. (2010): The Location Choice of Foreign Direct Investment Within Turkey: An Empirical Analysis. European Planning Studies, Vol. 18, No. 10, p. 1675-1705.

YILMAZ, S., YILMAZ, I. (2008): Evaluation of the wholesale market system for fresh fruits and vegetables in Turkey: A case study from Antalya Metropolitan Municipality. New Zealand Journal of Crop and Horticultural Science, Vol. 36, No. 2, p. 85-95.

\section{Authors' addresses:}

Dr. Martin FRANZ, e-mail: martin.franz@geo.uni-marburg.de

Alexandra APPEL, e-mail: alexandra.appel@geo.uni-marburg.de

Prof. Dr. Markus HASSLER, e-mail: markus.hassler@geo.uni-marburg.de

Faculty of Geography, Philipps-Universität Marburg

Deutschhausstr. 10, 35032 Marburg, Germany

Initial submission 23 July 2013, final acceptance 11 October 2013

Please cite this article as:

FRANZ, M., APPEL, A., HASSLER, M. (2013): Short waves of supermarket diffusion in Turkey. Moravian Geographical Reports, Vol. 21, No. 4, p. 50-63, DOI: $10.2478 / \mathrm{mgr}-2013-0020$. 